\title{
Crude Oil Price and Exchange Rates - The Case of Malaysia and Brunei
}

\author{
Abdul Razak Abdul Hadi ${ }^{1}$, Hafezali Iqbal Hussain ${ }^{2}$, Zalina Zainudin ${ }^{1}$ \& Raja Rehan ${ }^{1}$ \\ ${ }^{1}$ University Kuala Lumpur Business School, Kuala Lumpur, Malaysia \\ ${ }^{2}$ Taylor's University, Malaysia \\ Correspondence: Abdul Razak Abdul Hadi, University Kuala Lumpur Business School, Kuala Lumpur, Malaysia.
}

Received: April 30, 2019

Accepted: May 30, 2019

Online Published: June 10, 2019

doi:10.5430/ijfr.v10n5p1

URL: https://doi.org/10.5430/ijfr.v10n5p1

\begin{abstract}
This study is driven by the motivation to investigate the impacts crude oil price fluctuations on Malaysian and Brunei exchange rates as proxied by RM/USD and BD/USD respectively. Even though there is no specific economic theories that can help explain the interaction between commodity and foreign exchange markets, the study is research-worthy as both Malaysia and Brunei are major oil-exporting countries in South East Asia. This study is considered quite extensive involving 370 data points spanning from January 1988 till October 2018. Using Engle-Granger 2-Step Cointegration Test (1987) as an estimation tool, the empirical results show the presence of long-term equilibrium relationship between the two national currencies and crude oil price. Interestingly, there is also a significant short-run causality between them in both countries. With respect to the short-run dynamics, there is a unidirectional causality running from crude oil price to the two exchange rates. The study also posits that RM is less prone to changes in crude oil price during the period before Asian Debt Crisis in 1997. After the removal of RM peg in June 2005, RM is found to be more sensitive towards changes in crude oil price over short haul. In summary, the significant equilibrium and dynamic relationships between the national currencies and crude oil price are therefore confirmed and perhaps the quotation of crude oil price in USD could be one of the explanations.
\end{abstract}

Keywords: Malaysian exchange rate, Brunei exchange rate, Asian debt crisis 1997, Engle-Granger cointegration test, West Texas intermediate price and OPEC

\section{Introduction}

In December 2016, Malaysia, Brunei and other non-OPEC members negotiated with Organization of Petroleum Exporting Countries (OPEC) to reach an agreement to cut production so as to stabilize the price of crude oil. The fact is plummeting crude oil price affects the economy of all oil producing countries. Both Malaysia and Brunei are the major exporters of crude oil in South East Asia and it is intriguing to investigate to what extent that changes in crude oil price over the past thirty years could affect Malaysia and Brunei exchange rates. The fluctuation in crude oil prices since August 2014 has caused many oil-producing countries, particularly their governments to review their fiscal and monetary policy (Abdul Hadi and Yap, 2012; Anunciação, et. al 2016). The Asian Debt Crisis in 1997 is one of the important events that have influenced the way South East Asia governments manage their foreign currencies. This financial meltdown has led the world to witness how Malaysia turned down the prescription given by International Monetary Fund (IMF) and decided to peg its Ringgit Malaysia (RM) to USD, coupled with massive domestic government borrowing (Baharumshah et al., 2009). Malaysia had its RM Peg to USD in September 1998, while Brunei had its Brunei Dollar (BD) peg to SGD in 1967 under the Currency Interchangeability Agreement. Malaysia and Brunei are picked because both are Malay sultanate centred in South East Asia and they are also non-OPEC countries. This study is motivated to investigate the causal-effect relationship between national currencies and movements of crude oil prices from January 1988 till October 2018. The RM/USD and BD/USD are the variables of interest, while crude oil price is assigned as the explanatory variable. The crude oil price has started to decline since September 2014 and it reached the bottom of USD37 per barrel in March 2016. Such a price swing detrimentally affects the oil and gas industry, particularly the revenue from export activities. This study is narrowed towards a number of pertinent issues within the international trade theory.

It has been argued that the soaring in the crude oil price has strengthened RM in tandem with the adjustment of base lending rate in the financial market. In the past, a rise in crude oil price led to increase in US Dollar exchange rate due to a change in current account deficit which depreciates the local currency (Anwar, 2018;Beckmann and Czudaj, 2013; 
Nazlioglu and Soytas, 2011). Previous studies have recognized the significant relationship between crude oil price and major currencies such as US Dollar and Euro (Haseeb, Abidin, Hye \& Hartani, 2018; Bénassy-Quéré, Mignon, Penot, 2007). Johansen and Juselius (1990) acknowledge the presence of strong relationship between crude oil price and the currency rate such as USD/EURO rate. The relationship between crude oil price and currency also depends on the distribution of oil imports across oil-importing countries and non-oil-importing countries (Bénassy-Quéré, Mignon, Penot, 2007; Syadullah, 2018).

There are several theories that explain the market mechanisms of the crude oil price; the terms of trade channel (Buetzer et al, 2016), the wealth effect channel (Krugman, 1983), the portfolio reallocation channel (Bénassy-Quéré, Mignon, Penot, 2007; Wonyra, 2018; Atici, 2018) and international Fisher effect (Krugman, 2008; Tsung-Te, 2018). The terms of trade theory postulates that if the non-tradable sector of a country A is more energy intensive, the output price of this sector will increase relative to the output price of country B. Thus, effects on the nominal exchange rate arise if the price of tradable goods is no longer assumed to be fixed. In this case, inflation and nominal exchange rate dynamics are related via purchasing power parity (Jermsittiparsert, 2016). If the crude oil price increases, then the currencies of countries with large oil dependence in the tradable sector will depreciate due to higher inflation. The wealth channel theory reflects the resulting short-run effect, while the portfolio reallocation channel theory assesses medium- and long-run impacts on the crude oil price on the real exchange rate (Bénassy-Quéré, Mignon, Penot, 2007). When oil prices rise, wealth is transferred to oil exporting countries (in US dollar terms) and is reflected as an improvement in exports and the current account balance in domestic currency terms. Thus, the currencies of oil-exporting countries appreciate, and currencies of oil-importers depreciate in effective terms after a rise in oil prices (Beckmann and Czudaj, 2013). The wealth effect on the US dollar appreciates in the short-run because oil-exporting countries reinvest their revenues in US dollar assets. The portfolio effect on the currency are due to two factors: Oil exporters' relative preferences for US dollar assets and the dependence of the United States on oil imports relative to the share of US exports to oil-producing countries (Bénassy-Quéré, Mignon, Penot, 2007; Buetzer et al., 2016; Umaru \& Ombugus 2017; Azis, 2018).

In terms of crude oil production, it is evident that Malaysia has been enjoying more rapid growth since 1970 as compared to Brunei (see Figure 1). The growth in Malaysia crude oil production started to slow down in 1997 and the downward trend was clearly detected in 2008. Brunei, on the other hand, has been producing crude oil within a band $(110,000$ barrels $-250,000$ barrels/day) and the down trend has been identified in 2008 as well.

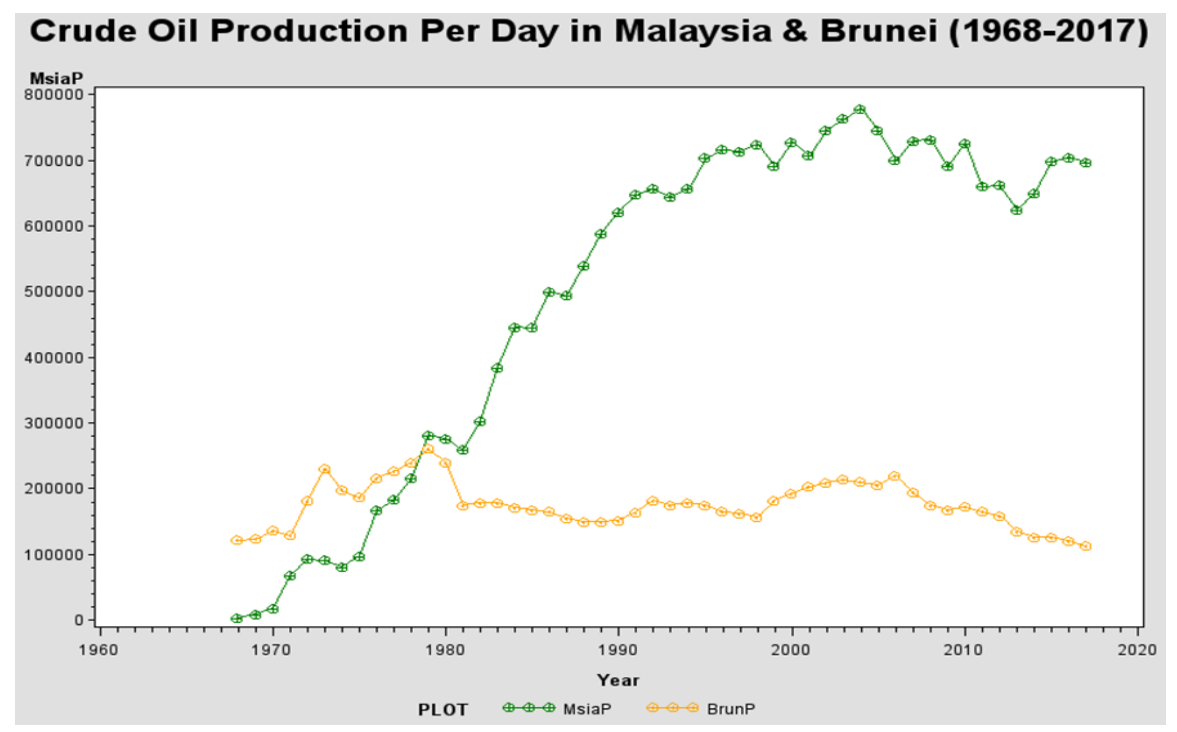

Figure 1. Crude oil production per day in Malaysia and Brunei (1968-2017)

The descriptive statistics on daily crude oil production in Malaysia and Brunei are summarized in Table 1 below. It is obvious that Malaysia's mean production is much higher than Brunei, but in terms of production variability, Brunei 
seems to be more unwavering than Malaysia. The standard deviation of crude oil production in Malaysia is almost seven times higher than Brunei and its max-min spread is seen very much wider.

Table 1. Descriptive statistics of crude oil production (Barrel/Day)

\begin{tabular}{llllll}
\hline Variable & $\mathbf{N}$ & Mean & Std Dev & Minimum & Maximum \\
\hline MsiaP & 50 & $501,447.40$ & $256,549.26$ & $4,000.00$ & $778,480.00$ \\
\hline BrunP & 50 & $175,891.40$ & $34,496.25$ & $113,170.00$ & $261,000.00$ \\
\hline
\end{tabular}

\section{Data \& Methodology}

This study is streamlined towards explaining the theoretical link between exchange rates and crude oil price. Given the fact that Malaysia and Brunei are crude oil-producing countries, the tax collections from the oil and gas industry has been a worthy source of revenue, which in turn increase demand for their domestic currencies. As such, changes in crude oil price are likely to influence the relative strength of RM and BD against USD. The crude oil price is proxied by West Texas Intermediate (WTI) whilst exchange rates are represented by RM/USD and BD/USD. The study uses monthly secondary data spanning from January 1988 through October 2018, involving 370 data points. The data of RM and BD exchange rates are obtained from World Bank database, while WTI prices are extracted from U.S Department of Energy.

\subsection{Empirical Model}

The time series model is deployed and empirically formulated as follows:

$$
\mathrm{ER}_{\mathrm{t}}=\mathrm{a}-\beta 1 \mathrm{WTI}_{\mathrm{t}}+\varepsilon_{\mathrm{t}}
$$

Where:

$\mathrm{ER}=$ Exchange Rate as proxied by RM/USD and $\mathrm{BD} / \mathrm{USD}$ respectively

$\mathrm{a}=$ Intercept

WTI $=$ Crude Oil Price as proxied by West Texas Intermediate

$\mathrm{t}=$ Time series $(\mathrm{t}=1,2.3 \ldots \mathrm{k})$

$\varepsilon_{\mathrm{t}}=$ Model Error Terms

From the empirical model, the study stipulates negative relationship between ER and WTI. In theory, an increase in crude oil price will generate incremental revenue from oil export activities which in turn strengthen the national currencies. The relative strength of both RM and BD (henceforth, national currencies) against USD are observed over the full sample period from 1988 till 2018. Similarly, the period before RM peg is also put into test. Due to the deteriorating financial market conditions throughout Asia from mid-1997 through1998, Malaysian government decided to implement RM peg to USD at RM3.80 per USD in 1 September 1998 so as to ward off continued currency speculative attacks over RM. It is somehow still debatable as to what extent that this intervention policy has been deemed successful. As such, a sub-period after RM peg dating from July 2005 till October 2018 is re-examined and its empirical evidence is presented.

The movements of national currencies and WTI are analysed and presented in Figure 2 and Figure 3 below. It is evident that WTI seems more volatile as demonstrated by its erratic movements. The highest level of WTI was recorded in June 2008 standing at USD133.88. At this point, RM was trading at RM3.2665 per USD. 


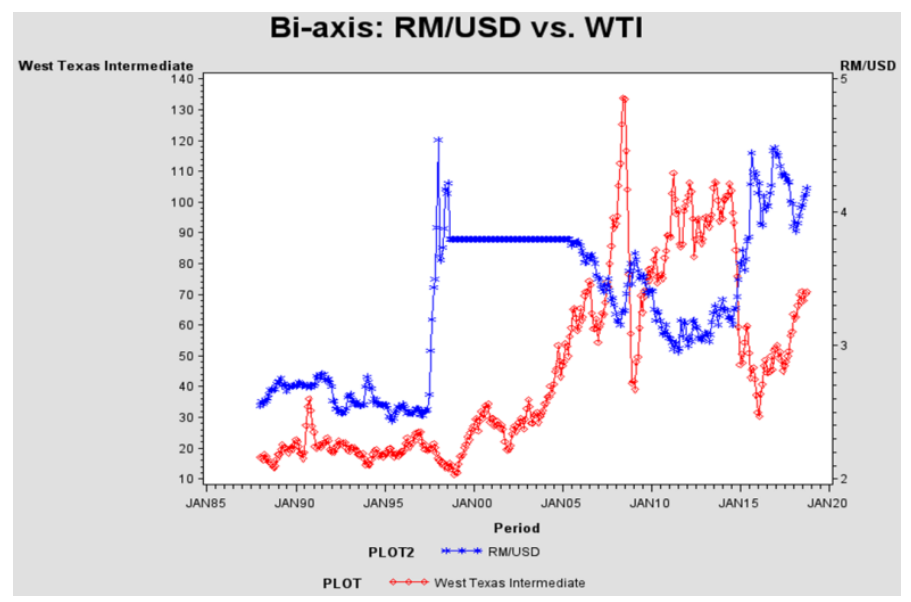

Figure 2. Movements of RM exchange rate and WTI: 1988-2018

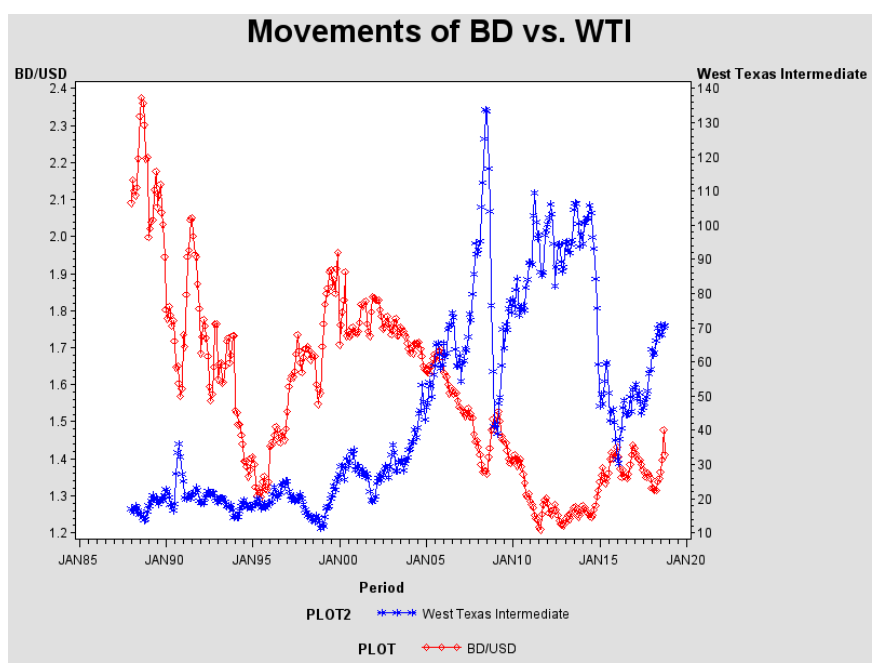

Figure 3. Movements of BD exchange rate and WTI: 1988-2018

In investigating the lead-lag relationship in the empirical model, the study employs Engle Granger Cointegration Test (1987). This estimation method (henceforth, EG) is selected due to its unique strength in explaining short-term and long-term relationships. EG is considered as one of the best econometrics time series tools and this error corrections technique was first advanced by Granger (1981) and later improved by Granger-Weiss in 1983. The modification process was continued by Granger and eventually finalized in the following year by both Engle and Granger. As a result of its dynamism, EG estimation technique is preferred by researchers who use it in testing the validity of various financial and economic theories (Ukwueze, Asogwa \& Odo 2018).

To perform EG 2-step cointegration approach, the following equation is specified:

$$
\Delta \mathrm{Y}_{\mathrm{t}}=\mu_{\mathrm{i}}+\sum_{\mathrm{i}=1}^{\mathrm{n}} \mathrm{A}_{\mathrm{i}} \Delta \mathrm{Y}_{\mathrm{t}-\mathrm{i}}+\sum_{\mathrm{i}=1}^{\mathrm{n}} \xi_{\mathrm{i}} \Theta \mathrm{t}_{\mathrm{t}-\mathrm{i}}+\mathrm{v}_{\mathrm{t}}
$$

where:

$\mathrm{Y}_{\mathrm{t}}$ has the form of $\mathrm{n} \mathrm{x} 1$ vector

$\mathrm{A}_{\mathrm{i}}$ and $\xi_{\mathrm{i}}$ are the estimated parameters

$\Delta$ is the difference operator

$v_{t}$ is the reactional vector which explains unanticipated movements in $Y_{t}$ and $\Theta$ (error correction term) 
As mentioned earlier, the EG technique allows separation of short-term adjustment from long-term relationships. The Ordinary Least-Squares method (OLS) is still part of the EG estimation technique and the 2-step procedures are as follows: (i) stationarity test must be performed on the long-run residuals (ii) second regression must be carried out upon the differenced variables. The estimation model's fundamental assumptions must be observed so as to validate the empirical findings. In probing the directional relationship involving the variable of interest and its explanatory variable, the study assumes that WTI influences the national currencies. This is based on the premise that changes in crude oil prices will later on affect oil-exporting country's terms of trade, which in turn influences its currency's value.

\section{Empirical Findings}

To start with, the correlation matrix among all the tested variables is presented in Table 2. From the exchange rate viewpoint, the RM demonstrates relatively positive low correlation with WTI as compared with BD. In contrast to RM, there is a strong negative correlation between BD and WTI.

Table 2. Pearson correlation analysis

\begin{tabular}{|c|c|c|c|}
\hline \multicolumn{4}{|c|}{$\begin{array}{l}\text { Pearson Correlation Coefficients, } N=370 \\
\text { Prob }>|\mathbf{r}| \text { under H0: } R h o=0\end{array}$} \\
\hline & WTI & $\mathbf{R M}$ & BD \\
\hline WTI & 1.00000 & 0.19035 & -0.66367 \\
\hline West Texas Intermediate & & 0.0002 & $<.0001$ \\
\hline $\mathbf{R M}$ & 0.19035 & 1.00000 & -0.10919 \\
\hline RM/USD & 0.0002 & & 0.0358 \\
\hline BD & -0.66367 & -0.10919 & 1.00000 \\
\hline $\mathrm{BD} / \mathrm{USD}$ & $<.0001$ & 0.0358 & \\
\hline
\end{tabular}

Table 3 below depicts the test results from Error Correction Model at lag 1 (Henceforth, ECM) over full sample period. The $l r$ is the model's coefficient of error correction term that explains both equilibrium relationship between tested variables plus their speed of adjustment. Basing on $l r$ 's negative value and its p-value in Table 2, we can deduce that there is a statistically significant long-run relationship between RM and WTI. Statistical procedure requires the p-value to be divided by two because ECM lies on the premise of one-tail residuals distribution (Granger's Representation Theorem, 1987). The $l r$ 's negative value of 0.0126 infers $1.26 \%$ speed of adjustment at which RM returns to equilibrium after a change in other variables. This is a converging process made by RM at relatively slow pace in the long run. At this point, it is confirmed that both RM and WTI are cointegrated. Furthermore, the presence of short-term dynamic relationship between RM and WTI is also observed in this model.

Table 3. Malaysia's error correction model at lag 1: full period (Jan 1988-Oct 2018, N=370)

\section{Parameter Estimates}

Dependent Variable: drm

\begin{tabular}{lllllll}
\hline Variable & DF & Parameter Estimate & Standard Error & T Value & Pr $>|\mathbf{t}|$ & Variance Inflation \\
\hline Intercept & $\mathbf{1}$ & 0.00466 & 0.00475 & 0.98 & 0.3272 & 0 \\
\hline Ldwti & $\mathbf{1}$ & -0.00215 & 0.00110 & -1.95 & $0.0516^{*}$ & 1.02659 \\
\hline Lr & $\mathbf{1}$ & -0.01269 & 0.00857 & -1.48 & $0.1395^{*}$ & 1.00814 \\
\hline Ldrm & $\mathbf{1}$ & -0.00319 & 0.05289 & -0.06 & 0.9519 & 1.03481 \\
\hline
\end{tabular}

*significant at $10 \%$ level

Similar to test results from Table 3, the empirical findings from Table 4 below are somewhat consistent. There are significant long-term and short-term relationships between BD and WTI over the full sample period. The error correction term in this Brunei model is relatively higher. The speed of adjustment of $3.44 \%$ towards equilibrium is made by $\mathrm{BD}$ in the system. 
Table 4. Brunei's error correction model at lag 1: full period (Jan 1988-Oct 2018, N=370)

\section{Parameter Estimates}

Dependent Variable: dbd

\begin{tabular}{lllllll}
\hline Variable & DF & Parameter Estimate & Standard Error & T Value & Pr $>|\mathbf{t}|$ & Variance Inflation \\
\hline Intercept & $\mathbf{1}$ & -0.00169 & 0.00213 & -0.80 & 0.4256 & 0 \\
\hline Ldwti & $\mathbf{1}$ & -0.00093636 & 0.00049481 & -1.89 & $0.0592 *$ & 1.03118 \\
\hline Lr & $\mathbf{1}$ & -0.03441 & 0.01158 & -2.97 & $0.0032 *$ & 1.01212 \\
\hline Ldrm & $\mathbf{1}$ & 0.13190 & 0.05172 & 2.55 & 0.0112 & 1.02894 \\
\hline
\end{tabular}

Unlike the test results from Table 3, the empirical findings from Table 5 below are completely the opposite. There is no significant long-term and short-term relationships that could be established over the period before the introduction of RM Peg in September 1998. The foreign exchange market seemed informationally efficient and working very well during this period until massive market manipulations were initiated by currency speculators in mid-July 1997.

Table 5. Error correction model at lag 1: period before RM Peg (Jan 1988-Aug 1998, N=128)

\section{Parameter Estimates}

Dependent Variable: drm

\begin{tabular}{lllllll}
\hline Variable & DF & Parameter Estimate & Standard Error & T Value & Pr $>|\mathbf{t}|$ & Variance Inflation \\
\hline Intercept & $\mathbf{1}$ & 0.01359 & 0.01081 & 1.26 & 0.2110 & 0 \\
\hline Ldwti & $\mathbf{1}$ & -0.00345 & 0.00657 & -0.53 & 0.6004 & 1.00743 \\
\hline Lr & $\mathbf{1}$ & 0.01668 & 0.03242 & 0.51 & 0.6079 & 1.13372 \\
\hline Ldrm & $\mathbf{1}$ & -0.04429 & 0.09659 & -0.46 & 0.6473 & 1.14134 \\
\hline
\end{tabular}

From the trend line in Figure4, it is evident that RM is stable over the observed period and relatively less volatile compared to WTI. This is also the golden period when Malaysia was enjoying robust economic growth with staggering stock market performance. July 1997 was the turning point for the South East Asia economies and Thailand was the first country that took the direct hit from currency speculation.

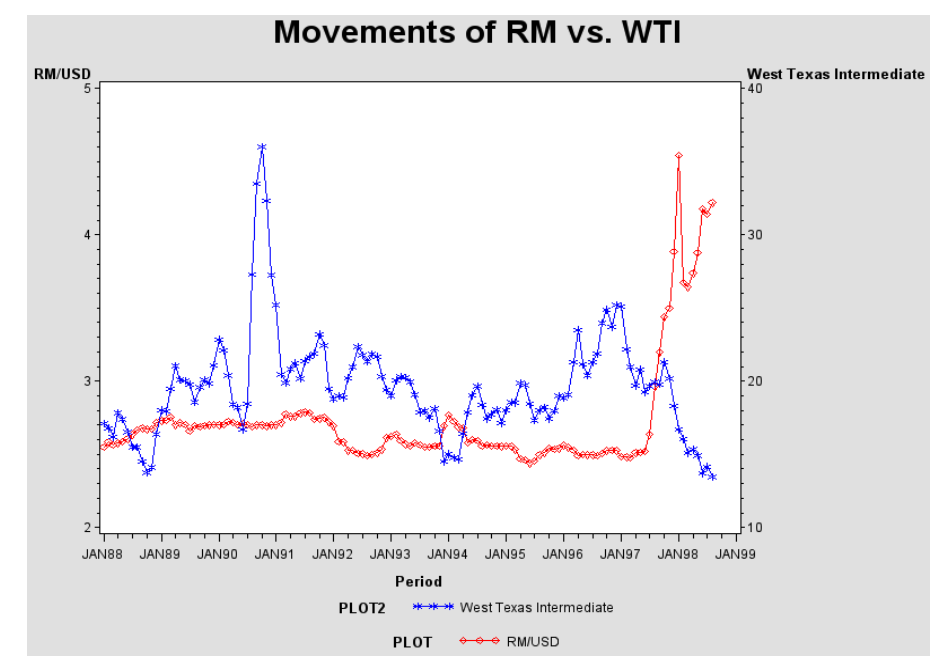

Figure 4. Movements of RM exchange rate and WTI: Jan 1988-Aug 1998

After the removal of RM peg to USD on 21 July 2005, RM is finally allowed to float in the foreign exchange market. From that moment, the short-term volatility of RM has been seen and vulnerable to many internal and external factors. Table 6 presents one of the important cases. Although there is an absence of equilibrium relationship between RM and 
WTI, their dynamic short-term relation is found to be significant at $10 \%$ level. The negative coefficient of $l d w t i$ signifies the inverse relationship between RM and WTI. An increase in WTI results in the strengthening of RM against USD in the short-run.

Table 6. Error correction model at lag 1: period after RM Peg (July 2005 - Oct 2018, N=160)

\section{Parameter Estimates}

Dependent Variable: drm

\begin{tabular}{lllllll}
\hline Variable & DF & Parameter Estimate & Standard Error & T Value & Pr $>|\mathbf{t}|$ & Variance Inflation \\
\hline Intercept & $\mathbf{1}$ & 0.00262 & 0.00660 & 0.40 & 0.6917 & 0 \\
\hline Ldwti & $\mathbf{1}$ & -0.00204 & 0.00111 & -1.83 & $0.0692 *$ & 1.09937 \\
\hline Lr & $\mathbf{1}$ & -0.00975 & 0.02686 & -0.36 & 0.7172 & 1.06899 \\
\hline Ldrm & $\mathbf{1}$ & 0.04057 & 0.08424 & 0.48 & 0.6308 & 1.12460 \\
\hline
\end{tabular}

*significant at $10 \%$ level

Figure5 demonstrates the co-movements of RM and WTI since the removal of RM Peg to USD in July 2005. It is so obvious that the two trend lines are moving in the opposite direction and both seem relatively volatile. The turbulence period started in September 2008, triggered by U.S subprime mortgage crisis and detrimentally affects the worldwide financial markets sentiment. Given technological breakthrough in U.S shale oil production since 2008, there has been excess supply of crude oil in the world market. This supply glut results in plummeting crude oil prices and income of oil-producing countries like Malaysia.

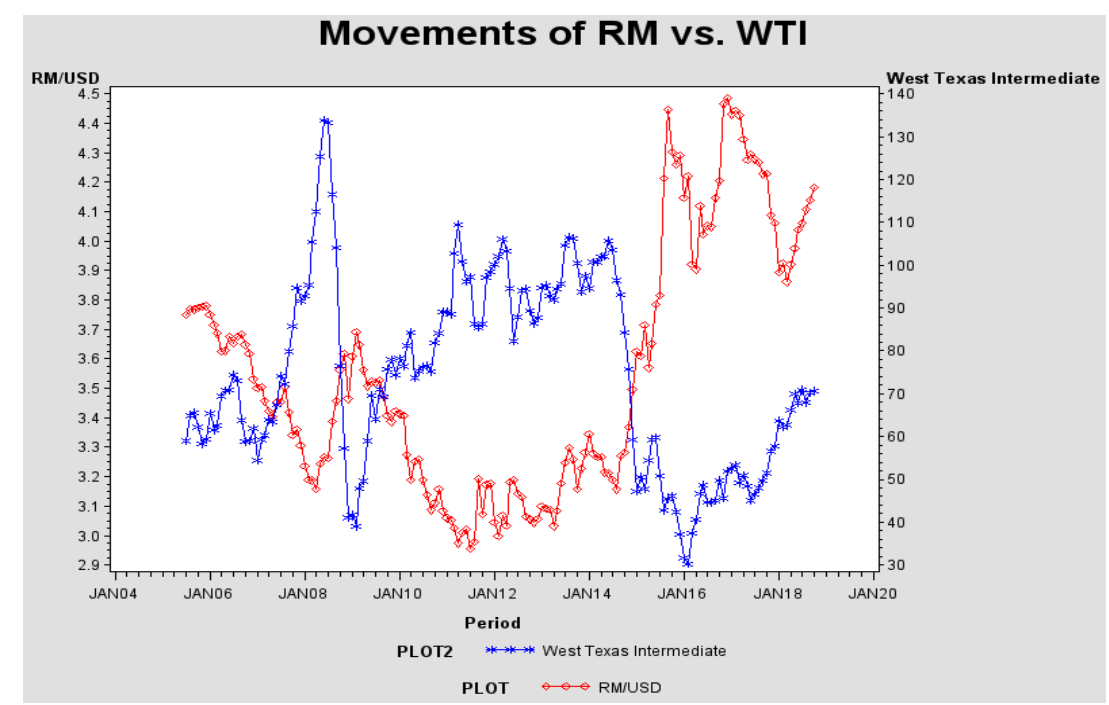

Figure 5. Movements of RM exchange rate and WTI: July 2005-Oct 2018

CUSUM analysis (or cumulative sum of residual test) is an important tool in econometric modelling. It is employed to tackle diagnostic problems related to parameter instability. From Figure 6 and Figure 6 below, the existence of parameter (short-run and long-run parameters) stability in these Malaysia and Brunei models are therefore confirmed. It is clear that the short-run residuals from the estimated model are lying within the lower and upper boundaries. As a whole, the predictive ER-WTI models, developed from this study, can be considered credible since no major diagnostic shortcomings are detected. 


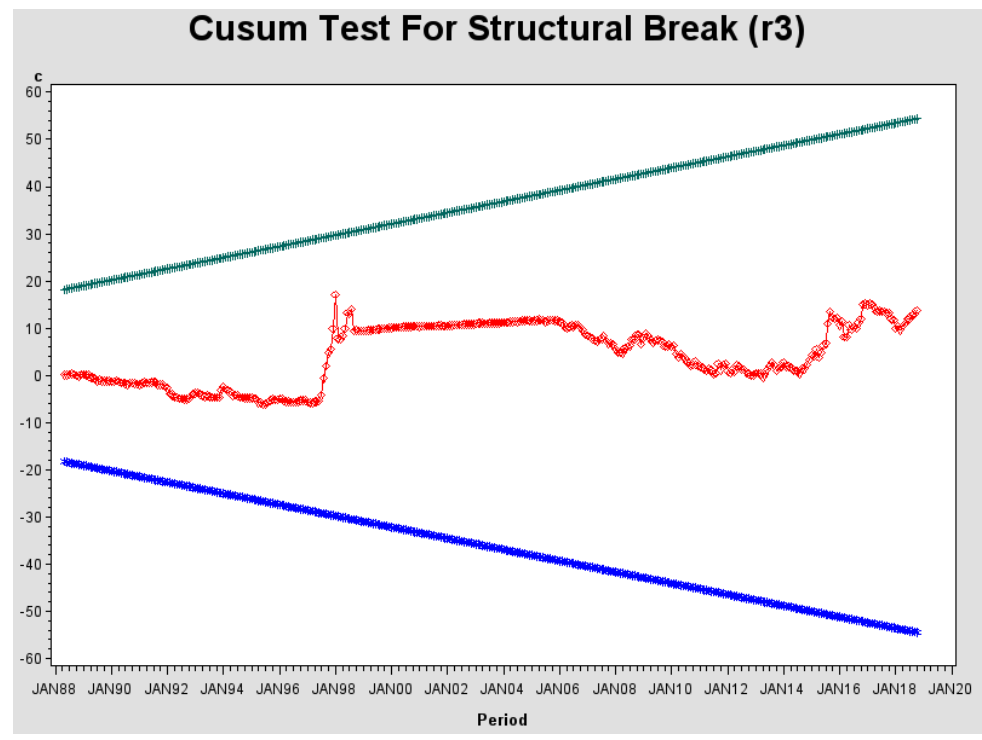

Figure 6. Cusum test of RM-WTI model (full sample: Jan 1988-Oct 2018)

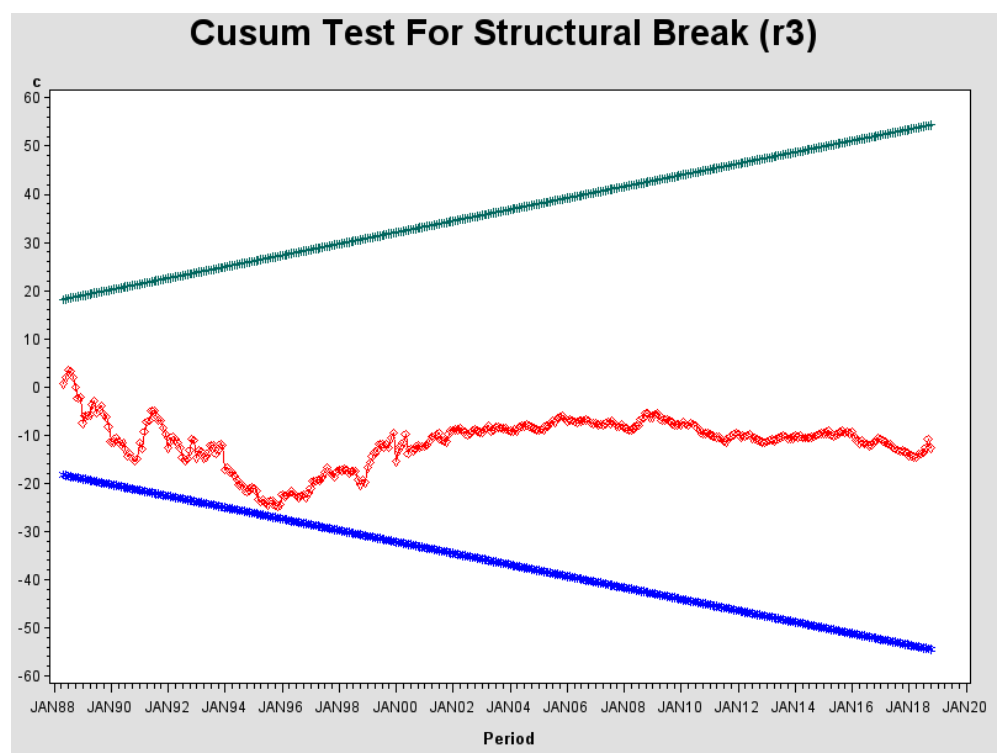

Figure 7. Cusum test of BD-WTI model (full sample: Jan 1988-Oct 2018)

It is important to understand the economic implications of changes in crude oil price on oil-producing country's exchange rate. In the case of Malaysia and Brunei, the observed period from 1988 through 2018 has provided some useful insights on how changes in commodity prices could influence the stability of national currencies. With regard to policy implication, this study has clearly shown that the plummeting crude oil prices in the long run will adversely affect a country's exchange rate and its competitiveness. From the empirical evidence, the period after the RM peg is the most challenging for the Central Bank of Malaysia to deal with, while Monetary Authority of Brunei manages the credit risk by continuing to peg BD to Singapore Dollar until today (Hassan, 2009).

\section{Conclusion.}

From the empirical evidence presented, the study unveils the presence of long-term and short-term relationships between the national currencies and WTI over full sample period. The RM is found to be less prone to changes in crude oil price during the period before Asian Debt Crisis in 1997. However, the present RM seems more vulnerable to changes in crude oil price in the short-run since the removal of RM peg in June 2005. Comparatively, the influence of 
crude oil price on exchange rate seems stronger in $\mathrm{BD}$ as compared to RM. This can be seen from the significant strong negative correlation between BD and WTI, coupled with higher speed of adjustment from Brunei's cointegration model. It is a known fact that there is no single monetary policy that any central bank could adopt to stabilize currency fluctuations. As a whole, this study provides one imperative perspective for policy makers. This study has proven that an export-driven policy by oil-producing countries has been the effective enabler that influences relative strength of domestic currencies in the long-run.

\section{References}

Abdul Hadi, A. R., \& Yap, T. H. (2012, June 1-3). Investigation on Effect of Changes in Crude Oil Prices on Malaysia Economy. $14^{\text {th }}$ Malaysian Finance Association Conference, Conference Proceedings, Park Royal Hotel Penang.

Anunciação, P., Hayashi, P. Jr., Abib, G., \& Batista, L. F. (2016). Ethics, Etiquette and Purpose of Life: In Search of the Coevolution's Missing Link in the Strategic Field. Asian Journal of Economics and Empirical Research, 3(1), 32-39. https://doi.org/10.20448/journal.501/2016.3.1/501.1.32.39

Anwar, M. N. (2018). Acquisition of Skills for Listening Comprehension: Barriers and Solutions. International Journal of English Language and Literature Studies, 7(3), 50-54. https://doi.org/10.18488/journal.23.2018.73.50.54

Atici, G. (2018). Islamic (Participation) Banking and Economic Growth: Empirical Focus on Turkey. Asian Economic and Financial Review, 8(11), 1354-1364. https://doi.org/10.18488/journal.aefr.2018.811.1354.1364

Azis, A. M. (2018). Layout Criteria for Enhancing Indonesian SMEs Production's Performance. International Journal of Emerging Trends in Social Sciences, 3(2), 80-85. https://doi.org/10.20448/2001.32.80.85

Baharumshah, Z. A., Mohd, S. H., \& Ahn, S. K. (2009). On the predictive power of monetary exchange rate model: the case of the Malaysian Ringgit/US Dollar rate. Applied Economics, 41, 1761-1770. https://doi.org/10.1080/00036840902817771

Beckmann, J., \& Czudaj, R. (2013). Oil prices and effective dollar exchange rates. International Review of Economics \& Finance, 27, 621-636. https://doi.org/10.1016/j.iref.2012.12.002

Bénassy-Quéré, A., Mignon, V., \& Penot, A. (2007). China and the relationship between the oil price and the dollar. Energy Policy, 35(11), 5795-5805. https://doi.org/10.1016/j.enpol.2007.05.035

Buetzer, S., Habib, M. M., \& Stracca, L. (2012). Global exchange rate configurations: do oil shocks matter?

Engle, R. F., \& Granger, C. W. J. (1987). Co-integration and Error Correction: Representation, Estimation and Testing. Econometrica, 55, 251-276. https://doi.org/10.2307/1913236

Engle, R. F., \& Yoo, B. S. (1987). Forecasting and testing in co-integrated systems. Journal of Econometrics, 35(1), 143-159. https://doi.org/10.1016/0304-4076(87)90085-6

Granger, C. W. J., \& Weiss, A. A. (1983). Time Series Analysis of Error-Correcting Models. Studies in Econometrics, Time Series and Multivariate Statistics, pp.255-278. New York: Academic Press. https://doi.org/10.1016/B978-0-12-398750-1.50018-8

Granger, C. W. J. (1981). Some Properties of Time Series Data and Their Use in Econometric Model Specification. Journal of Econometrics, 121-130. https://doi.org/10.1016/0304-4076(81)90079-8

Haseeb, M., Abidin, I. S. Z., Hye, Q. M. A., \& Hartani, N. H. (2018). The Impact of Renewable Energy on Economic Well-Being of Malaysia: Fresh Evidence from Auto Regressive Distributed Lag Bound Testing Approach. International Journal of Energy Economics and Policy, 9(1), 269-275.

Hassan, A. (2009). Risk management practices of Islamic banks of Brunei Darussalam. The Journal of Risk Finance, 10(1), 23-37. https://doi.org/10.1108/15265940910924472

Jermsittiparsert, K. (2016). Culture of 'Elephant front legs-hind legs': A debate on the actuality of sexual politics in Thai society. The Social Sciences, 11(1), 20-28.

Johansen, S., \& Juselius, K. (1990). Maximum likelihood estimation and inference on cointegration-with applications to the demand for money. Oxford Bulletin of Economics and statistics, 52(2), 169-210. https://doi.org/10.1111/j.1468-0084.1990.mp52002003.x

Krugman, P. (1983). New theories of trade among industrial countries. The American Economic Review, 73(2), 343-347. 
Krugman, P. R. (2008). International economics: Theory and policy (8th ed.). Pearson Education India.

Nazlioglu, S., \& Soytas, U. (2011). World oil prices and agricultural commodity prices: evidence from an emerging market. Energy Economics, 33(3), 488-496. https://doi.org/10.1016/j.eneco.2010.11.012

Syadullah, M. (2018). ASEAN banking efficiency review facing financial services liberalization: The Indonesian perspective. Asian Development Policy Review, 6(2), 88-99. https://doi.org/10.18488/journal.107.2018.62.88.99

Tsung-Te, L. (2018). Trade Dependence within Greater China: Economy and Trade Between Mainland China, Taiwan and Hong Kong. Asian Journal of Economic Modelling, 6(2), 203-207. https://doi.org/10.18488/journal.8.2018.62.203.207

Ukwueze, E., Asogwa, H. T., \& Odo, A. C. (2018). Nigerian Enterprise Sector and Policy Uncertainty. Asian Journal of Economic Modelling, 6(2), 110-120. https://doi.org/10.18488/journal.8.2018.62.110.120

Umaru, R. I., \& Ombugus, D. A. (2017). Determinants of job satisfaction of Colleges of Education Lecturers: A study of Nasarawa State College of Education, Akwanga. Asian Business Research Journal, 2(1), 8-13. https://doi.org/10.20448/journal.518.2017.21.8.13

Wonyra, K. O. (2018). Impact of Telecommunications Market Liberalization on Labor Productivity in Economic Community of West African States. Journal of Social Economics Research, 5(2), 63-74. https://doi.org/10.18488/journal.35.2018.52.63.74 